\title{
Oestrogen receptors in mucinous carcinoma of the breast: an immunohistological study using paraffin wax sections
}

\author{
S SHOUSHA, A T COADY, TINA STAMP, K R JAMES, J ALAGHBAND-ZADEH* \\ From the Departments of Histopathology and *Chemical Pathology, Charing Cross Hospital and Charing Cross \\ and Westminster Medical School, London
}

SUMMARY An immunohistological method (Shintaku-Said method) for the demonstration of oestrogen receptors in routinely processed paraffin wax embedded tissue was applied to 19 cases of mucinous carcinoma of the breast. Seventeen (89\%) tumours showed variable degrees of positivity and two were negative. In eight cases the receptors were also assayed biochemically using a dextrancoated charcoal method, and the results of the two methods showed good correlation. No difference in the distribution of positive and negative cases was noted between pure and mixed mucinous tumours, and in the latter group the pattern of staining of the mucinous elements was similar to that seen in the solid elements.

It is concluded that the major advantage of this method is its ability to offer for study the distribution of the receptors in individual cells and specific histological structures. The results also indicate that most mucinous carcinomas of the breast are oestrogen receptor positive, irrespective of whether they are pure or mixed type.

Mucinous carcinomas of the breast may occur in a pure or a mixed form. ${ }^{12}$ In the pure form the neoplastic cells may be argyrophilic or non-argyrophilic. ${ }^{3-5}$ In the mixed form part of the tumour is composed of solid elements which may be invasive ductal, invasive lobular, papillary, adenocystic, tubular or a combination of these. ${ }^{2}$ Distinction between these forms is important as it has a bearing on the prognosis. ${ }^{15-7}$

The oestrogen receptor content of mucoid breast carcinoma has been discussed previously in several reports. $^{8-15}$ In none of these was the distinction between the various forms made; and it is not clear whether the cases discussed in these reports were all of the pure form or included some mixed forms; and consequently the histological type of the solid component of any mixed form that might have been included was not specified. These details may be important when studying the correlation between the histological types of tumours and their receptor content.

An immunoperoxidase method for the detection of oestrogen receptors in routinely processed, paraffin wax embedded tumour tissue was published recently. ${ }^{16}$

Accepted for publication 31 March 1989
This retrospective study was aimed at applying this method on 19 cases of mucinous carcinoma of various subtypes. The validity of the technique was assessed by comparing the immunohistological results with those obtained by the standard dextran-coated charcoal biochemical assay which was carried out on eight cases.

\section{Material and methods}

Nineteen cases of mucinous carcinoma of the breast were retrieved from the files of the histopathology department. Cases were divided into two main groups: pure mucinous when all the invasive neoplastic elements were surrounded by mucin; and mixed mucinous where part of the invasive carcinoma was composed of solid elements not surrounded by mucus. The pure cases were further subdivided into two subgroups according to the absence or presence of argyrophilic granules in the neoplastic cells. The full clinical and histopathological data of these tumours are reported elsewhere. ${ }^{5}$

A representative section was chosen from each case and sections $(5 \mu \mathrm{m})$ were cut from the corresponding formalin fixed, paraffin wax embedded block of 
tumour tissue. The sections were dewaxed, hydrated through graded alcohols, and rinsed in TRIS buffer (pH 7.6). Endogenous peroxidase activity was reduced by using $0.5 \%$ hydrogen peroxide in methanol for 10 minutes. The method described by Shintaku and Said for the demonstration of oestrogen receptors in paraffin wax sections ${ }^{16}$ was then used. Briefly, the sections were covered with DNase I solution (Sigma, D-5025) in a humid chamber for two hours, rinsed in TRISbuffered saline (TBS), incubated for 30 minutes in normal goat serum and then incubated overnight with several drops of the ER-ICA monoclonal antibody (Abott Laboratories, England). This was followed by rinsing in TBS, one hour of incubation in goat antirabbit immunoglobulin, and another hour of incubation in peroxidase-anti-peroxidase complex. Sections were then rinsed in TBS, incubated in diaminobenzine for 10 minutes, washed in tap water and lightly counterstained with haematoxylin. A control slide from each case was treated in the same way except for replacing the specific antiserum with the negative control antibody supplied with the ER-ICA kit.

The staining results were assessed semiquantitatively according to the percentage of cells stained and the intensity of the staining. For each of these two components a scale of 1-3 was used. For percentage staining 1 referred to the presence of positive staining in less than $33 \%$ of tumour cells, 2 for $33-66 \%$, and 3 for the presence of more than $66 \%$ positively stained cells. For intensity, 1 indicated weak staining, 2 moderate, and 3 strong staining. The two factors were multiplied by each other, and the final result expressed as follows: $-=$ negative (no staining); $+=$ weakly positive (for a total score of $1-3$ ); $++=$ moderately positive (score 4-6); and $+++=$ strongly positive (score >6).

In eight cases oestrogen receptors were assayed by the dextran-coated charcoal method, ${ }^{17}$ using tumour tissue stored in liquid nitrogen. Tumours with an oestrogen receptor concentration of less than $10 \mathrm{fmol} /$ mg cytosol protein were considered to be negative.

\section{Results}

Using the immunohistological method, staining for oestrogen receptors was restricted to the nuclei of neoplastic cells (fig 1) and some normal looking ductal epithelial cells. No cytoplasmic, stromal, or background staining was seen. Seventeen out of the 19 tumours $(89 \%)$ were receptor positive and two were negative (table). All positive tumours had negative as well as positive cells; hence the use of the ratio between these, together with the intensity of staining, as the basis for the semiquantitative assessment.

There was no apparent difference in the distribution of negative and various positive cases between the two main groups of pure and mixed mucinous tumours

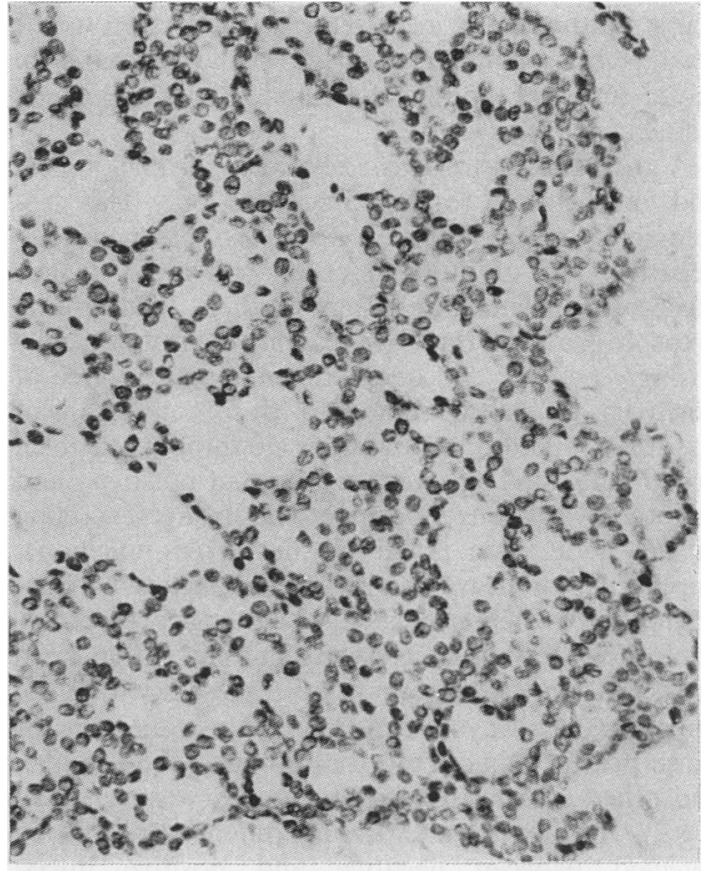

Fig 1 Pure mucinous carcinoma with argyrophilic granules. The tumour is highly cellular and the cells are arranged in a cribriform pattern surrounded by mucin. The nuclei show a moderate degree of staining for oestrogen receptors.

Table Oestrogen receptors in mucinous carcinoma of the breast

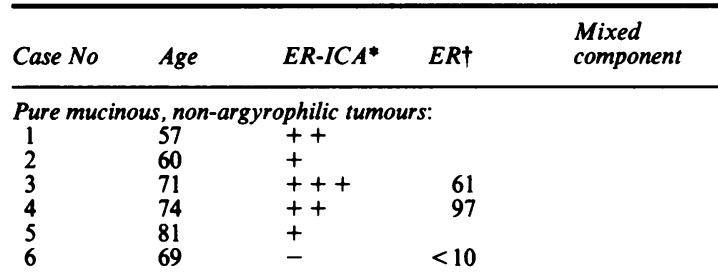

Pure mucinous, arygrophilic tumours:

$\begin{array}{rlc}\text { Pure mucinous, arygrophilic tumours } \\ 7 & 83 & ++ \\ 8 & 81 & ++ \\ 9 & 74 & +++ \\ 10 & 72 & +++ \\ 11 & 64 & + \\ 12 & 76 & +++\end{array}$

Mixed mucinous tumours:

\begin{tabular}{|c|c|c|c|c|}
\hline $\begin{array}{l}13 \\
14 \\
15 \\
16 \\
17 \\
18 \\
19\end{array}$ & $\begin{array}{l}68 \\
68 \\
66 \\
81 \\
75 \\
80 \\
36\end{array}$ & $\begin{array}{l}+ \\
+ \\
+++ \\
+++ \\
+++ \\
++ \\
+\end{array}$ & $\begin{array}{r}0 \\
992 \\
477 \\
363 \\
313\end{array}$ & $\begin{array}{l}\text { Ductal } \\
\text { Ductal } \\
\text { Papillary } \\
\text { Ductal } \\
\text { Ductal } \\
\text { Ductal } \\
\text { Ductal }\end{array}$ \\
\hline
\end{tabular}

*ER-ICA = immunohistologically confirmed oestrogen receptors: -negative, +weakly positive, ++ moderately positive, +++ strongly positive.

$\mathrm{TER}=$ Biochemically assayed oestrogen receptors in $\mathrm{fmol} / \mathrm{mg}$ cytosol protein. 
(table), although no negative cases were seen in the small subgroup of pure, argyrophilic tumours. In mixed tumours the mucinous and solid components stained similarly.

A good correlation existed between the histological and biochemical results. Thus the only two histologically negative cases were also biochemically negative; and of the four cases with an oestrogen receptor concentration of more than $300 \mathrm{fmol} / \mathrm{mg}$ cytosol protein, three were immunohistologically strongly positive and one had a moderate degree of positivity. Of the two tumours with concentrations of less than 100 but more than $50 \mathrm{fmol} / \mathrm{mg}$ cytosol protein, one had a moderate degree of positivity and the other was strongly positive. The strongest staining in this series was noted in the mixed mucinous/ papillary tumour, which also had the highest concentration of biochemically assayed oestrogen receptors.

Normal looking ducts were identified within or in the vicinity of 14 tumours. Those present within the tumour were always receptor negative, while some of those present adjacent to the tumour were positive, and others, around the same tumour, were negative (fig 2). No obvious microscopic differences could be detected between negative and positive ducts. Positively stained ducts tended to be slightly less intensely stained than the adjacent tumour, although in some cases the intensity was the same. Only one normal breast lobule was identified in the sections examined. The tumour in this case was positively stained for the receptors while the acini in the lobule were negative.

Foci of intraductal carcinoma were present in four cases. In each case the intensity of the staining in both the intraductal and invasive elements was similar. The intraductal carcinoma was of the papillary type in three cases (cases 4, 15 and 17), cribriform in two (cases 15 and 17) (fig 3), and comedo in one (case 19). The staining was strongest in the papillary and weakest in the comedo type. In the latter case the faint staining obtained was restricted to the outer layer of cells. Occasionally, ducts lined partly with normal epithelium and partly with neoplastic cells were seen. In these cases positive staining was restricted to the neoplastic cells.

\section{Discussion}

This study confirms that there is a good correlation between the Shintaku-Said method for the detection of oestrogen receptors in routinely processed paraffin wax embedded breast tumour tissue ${ }^{16}$ and the more established dextran-coated charcoal biochemical assay. This does not only mean that the histological method is reliable, but also confirms, looking at it the other way, that the biochemical results obtained in mucinous carcinoma reflect the true concentration of oestrogen receptors in the tumours, in spite of the presence of abundant mucin which might have been thought to lead to falsely low values.

The simple, semiquantitative scale used in this study for expressing the immunohistological results gave some idea about whether the tumour was poor, rich, of extremely rich in oestrogen receptors, this was alsen reasonably consistent with the biochemical resuits.

The most outstanding advantage of the immunohistological method is the ability it offers for the study of the distribution of the receptors in individual cells and specific histological structures. Thus the method clearly showed that a variable number of receptor

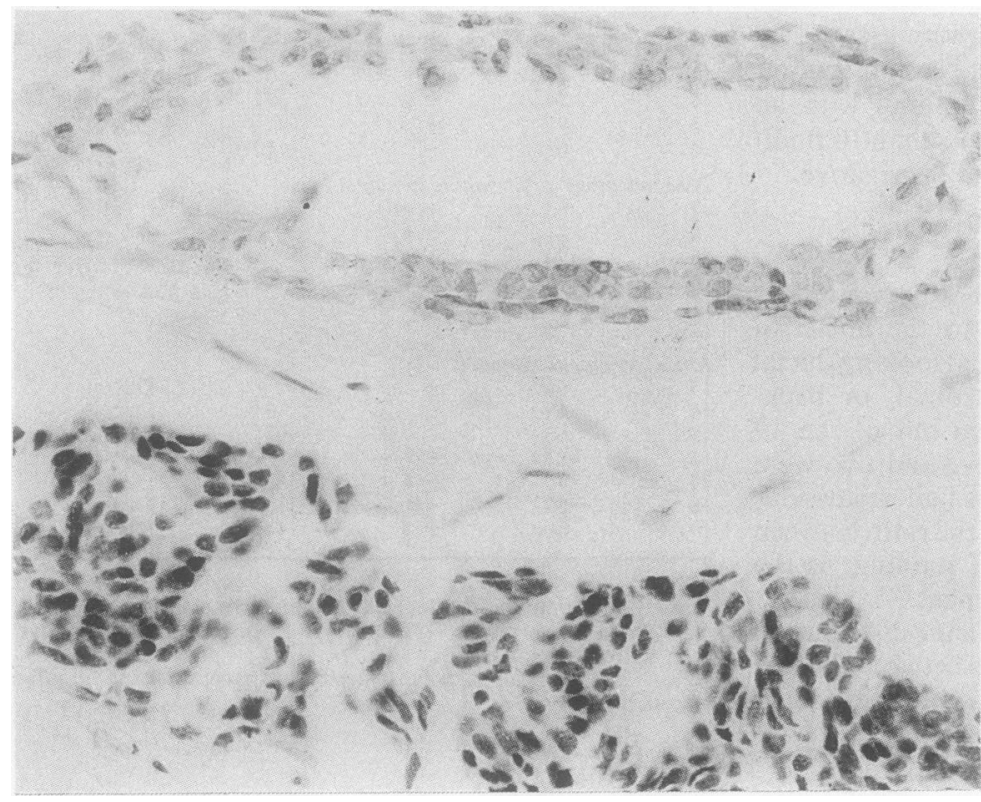

Fig 2 The solid part of a mixed mucinous/ductal carcinoma. Many nuclei of the invasive ductal elements are strongly stained for oestrogen receptors. A slightly dilated, but otherwise normal, duct in the upper half of the picture is receptor negative. 


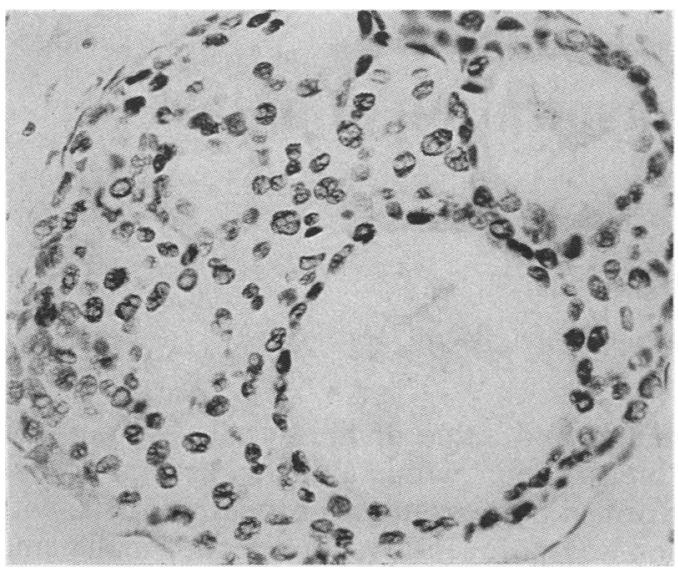

Fig 3 Cribriform intraductal carcinoma. Most of the nuclei are positively stained for oestrogen receptors.

negative cells were always present in every case, even those with extremely high concentrations of biochemically assayed receptors. It was also possible to study the distribution of the receptors in normal ducts and in various types of intraductal carcinoma present near the main tumour mass, and to compare the staining patterns of the mucinous and solid components of mixed tumours.

Normal ducts seen within the tumour were always negatively stained. In contrast, ducts in the immediate vicinity of the tumour varied in their reaction, with some being negative and others positive. The cause for this variation was not obvious and may be worth a larger and more detailed investigation.

Although the series was relatively small, the results suggest that the oestrogen receptor staining pattern of intraductal carcinoma tend to be similar to that of the associated invasive tumour. Of special interest is the finding that the strongest staining of intraductal carcinoma was seen in the papillary type, and the weakest in the comedo type as biochemical assays have previously shown high oestrogen receptor concentrations in invasive papillary tumours ${ }^{10} 18$ and low or undetectable concentrations in invasive comedo carcinoma. ${ }^{10}$

In mixed mucinous tumours receptor staining of the solid component was similar to that of the mucinous component. This, together with the previously mentioned similarity between the staining pattern of invasive and intraductal elements in the same tumour, suggest that in a given neoplasm at a given time, there is a consistency in the expression of oestrogen receptors in all the neoplastic structures, although variations may occur in individual cells.

It is concluded that the method used in this study for the detection of oestrogen receptors in routinely processed paraffin wax sections is reliable and gives results consistent with those obtained with the dextran-coated charcoal biochemical assay. The results also show that most mucinous carcinomas of the breast are oestrogen receptor positive, irrespective of whether they are of the pure or mixed type.
This study was supported by a grant from the Peel Medical Research Trust.

\section{References}

1 Norris HJ, Taylor HB. Prognosis of mucinous (gelatinous) carcinoma of the breast. Cancer 1965;18:879-85.

2 Fisher ER, Gregorio RM, Fisher B. The pathology of invasive breast cancer. A syllabus derived from findings of the National Surgical Adjuvant Breast Project (Protocol No. 4). Cancer 1975;36:1-85.

3 Capella C, Eusebi V, Mann B, Azzopardi JG. Endocrine differentiation in mucoid carcinoma of the breast. Histopathology 1980;4:613-30.

4 Ferguson DJP, Anderson TJ, Wells C, Battersby S. An ultrastructural study of mucoid carcinoma of the breast: variability of cytoplasmic features. Histopathology 1986;10:1219-30.

5 Coady AD, Shousha S, Dawson PM, Moss M, James KR, Bull TB. Mucinous carcinoma of the breast. Further characterisation of its three subtypes. Histopathology (In press).

6 Toikkanen S, Eerola E, Ekfors T. Pure and mixed mucinous breast carcinomas: DNA stemline and prognosis. J Clin Pathol 1988;41:300-3

7 Komaki K, Sakamoto G, Sugano H, Morimoto T, Monden Y. Mucinous carcinoma of the breast in Japan. A prognostic analysis based on morphologic features. Cancer 1988;61: 989-96.

8 Rosen PP, Menendez-Botet CJ, Nisselbarum JS, et al. Pathological review of breast lesions analysed for estrogen receptor protein. Cancer Res 1975;35:3187-94.

9 Millis RR. Correlation of hormone receptors with pathological features in human breast cancer. Cancer 1980;46:2869-71.

10 Silfverswards C, Gustafsson J-A, Gustafsson SA, et al. Estrogen receptor concentration in 269 cases of histologically classified human breast cancer. Cancer 1980;45:2001-5.

11 Lesser ML, Rosen PP, Senie RT, Duthie K, Menendez-Botet C, Schwartz MK. Estrogen and progesterone receptors in breast carcinoma: correlations with epidemiology and pathology.Cancer 1981;48:299-309.

12 Howat JMT, Barns DM, Harris M, Swindell R. The association of cytosol oestrogen and progesterone receptors with histological features of breast cancer and early recurrence of disease. $\mathrm{Br} \mathrm{J}$ Cancer 1983;47:629-40.

13 De Rosa CM, Ozzello L, Greene GL, Habif DV. Immunostaining of estrogen receptors in paraffin sections of breast carcinomas using monoclonal antibody D75P3: Effects of fixation. Am J Surg Pathol 1987;11:943-50.

14 Charpin C, Martin PM, DeVictor B, et al. Multiparametric study (SAMBA 200) of estrogen receptor immunocytochemical assay in $\mathbf{4 0 0}$ human breast carcinomas: Analysis of estrogen receptor distribution heterogeneity in tissues and correlations with dextran coated charcoal assays and morphological data. Cancer Res 1988;48:1578-86.

15 Reiner A, Reiner G, Spona J, Schemper M, Holzner JH. Histopathologic characterisation of human breast cancer in correlation with estrogen receptor status. A comparison of immunocytochemical and biohchemical analysis. Cancer 1988;61:1149-54.

16 Shintaku IP, Said JW. Detection of estrogen receptors with monoclonal antibodies in routinely processed formalin-fixed paraffin sections of breast carcinoma. Use of DNase pretreatment to enhance sensitivity of the reaction. Am J Clin Pathol 1987;87:161-7.

17 King RJB, Redgrave S, Hayward JL, Millis RR, Rubens RD. The measurement of receptors for oestradiol and progesterone in human breast tumours. In: King RJB, ed. Steroid receptor assays in human breast tumours. Methodological and clinical aspects. Cardiff: Alpha Omega, 1979:55-72.

18 Shousha S, Backhouse CM, Alaghband-Zadeh J, Burn I. Alveolar variant of invasive lobular carcinoma of the breast. A tumour rich in estrogen receptors. Am J Clin Pathol 1986;85:1-5.

Requests for reprints to: Dr S Shousha, Department of Histopathology, Charing Cross Hospital, Fulham Palace Road, London W6 8RF, England. 